\title{
ISLAMIC ETHICS AND STEM CELL RESEARCH
}

\author{
Fahm AbdulGafar Olawale*
}

\begin{abstract}
Application of Islamic Ethics to issues in the physical sciences is only in its infancy. Human stem cells are nature's self-renewing master cells, capable of generating every one of the numerous biological tissues in the human body. Their use in contemporary medicine for repairing organs and regenerating cellular tissues holds the promise of major treatments and cures. Summary overviews of the scientific context of stem cell research is provided, and of the controversy surrounding it. The contribution of Islamic Law and ethical tradition is then reviewed, focusing on the Higher Aims of the Shari'ah. Islam may assist in defining the ethical boundaries at the heart of this issue, and positively contribute to medical science in this field of enquiry.
\end{abstract}

\section{Introduction}

Ethics is a discipline concerned with what is right and how to maintain a good life. According to Pojman, "it [ethics] is the systematic endeavour to understand moral concepts and justify moral principles and theories. It undertakes to analyse such concepts as right, wrong, permissible, ought, good and evil in their moral contexts." Ethics is also sometimes used in reference to a set of rules, principles or ways of thinking that show, or claim authority to show, the action of a group of people, and in some instances stands for the systematic study of reasoning about how we ought to act. $^{2}$

Islamic ethics, which can be described as a section in religious ethics, does not exist as a separate and independent discipline in Islam. It draws most of its resources from revelation. Ethical teachings of Islam are closely linked to its theology. ${ }^{3}$ The sense of God's presence or God's guidance is seen as the guiding principle. Various teachings on ethics in Islam can be found in pages of Qur'anic commentaries, theology, jurisprudence, and mystical works. Islamic ethics, however, still faces the same set of questions facing philosophical ethics: what values should be pursued? What acts are right and what acts are wrong? How should society go about making ethical decisions posed by new challenges? ${ }^{4}$

Ethics as a discipline in Islam began to emerge as a result of the influence of Greek thought. ${ }^{5}$ Classical scholars of Islam when referring to moral philosophy in Islam often use the terms akhlāq or khuluq. For instance, Aḥmad ibn Muhammad Miskawayh wrote a book titled Tahdhīb al-Akhlāq. Akhlāq is a term commonly translated as character. Miskawayh in his famous work linked akhlāq to the soul. He believed that if humans understood what their soul is, what kind of beings they are, and for what purpose they have been created, Man would be able to perform good actions easily and reach a high state of mind. ${ }^{6} \mathrm{Al}$-Ghazālī in his 
Ihya $\bar{a}^{c}$ ulüm al-dìn also linked akhlāq to the state of the soul. He noted that human nature is rooted in the soul and actions flow out of it. ${ }^{7}$ He believed that $a k h l \bar{a} q$ is a term for the state of the soul and its inner or spiritual character. ${ }^{8}$

Islamic ethics can therefore be described as what is morally correct or morally acceptable in Islam. There are also some important words that we must be conscious of when considering Islamic ethics. They are: $\bar{\imath} m \bar{a} n$, islām, taqwā and $i h s \bar{a} n .{ }^{9}$ Imān means faith. taqwā means God consciousness, or the understanding of a Muslim that Allah sees him or her in every circumstance. Ihsān means excellence; Muslims are expected to do good always.

It is in relation to the notions and values in these words that we would try to understand the Islamic position in relation to stem cell research, but let us first define what stem cells are. These are known as nature's master cells, capable of generating every one of the many different cells that make up the body. They have the ability to self-renew, meaning that they are theoretically immortal and can divide forever if provided with enough nutrients, and since they are so plastic, they hold enormous power as a basis for new treatments and cures for various disorders ranging from Parkinson's and heart diseases to diabetes and spinal cord injuries. ${ }^{10}$ They are obtained from sources such as embryos, umbilical cords, and bone marrow. Stem cell research began quietly with the discovery in the mid1800 s that some cells could generate other cells. Today stem cell research is embroiled in controversy over the use of human embryonic stem cells (hESCs).

Despite all the contributions to research to date on stem cell therapy, there seem to have been few contributions from Muslim scholars. Learned Muslims and scholars would be expected to make their contributions, especially when we consider that Islam is a religion that provides guidance to mankind. The Qur'ān, for example, says: "This is a book; in it is sure guidance, without a doubt, to those who are God-fearing" (al-Baqarah 2:2).

Embryonic stem cell research is controversial because days-old embryos, sometimes called blastocysts, must be sacrificed to obtain the stem cells, and this means sacrificing a potential life, a situation that gives rise to great debate among ethicists, legal practitioners, sociologists and others. Those who value human life from the time of conception oppose ESC research. If human life in the form of an embryo less than two weeks after conception is a human person, then extracting stem cells constitutes murder; if it is not, then removing stem cells would be morally acceptable. Some people are of the opinion that an embryo is not sentient and has no brain, sensory organs, ability to think, memory, consciousness, internal organs, arms, legs or head. Since a blastocyst has no features related to human beings, ethical judgments pertaining to humans cannot be applied.

Islam can contribute to assessing what really constitutes human life, when human life really begins, and when we have the right to kill or conduct experiments 
involving some form of killing in order to cure a patient. By trying to find answers to these questions, Islamic ethics can make significant contributions to stem cell research.

Cell differentiation and immunological intolerance are key areas of scientific interest in stem cell therapy. Cells transplanted for therapy are taken from either adult or fetal or embryonic cells, and scientists believe transplants are best undertaken on embryonic cells, for they offer a more fundamental variety of cell and have the greatest capacity to become different types of body organs.

To further understand the scientific background of stem cells, some basic knowledge of cell biology is required. ${ }^{11}$

\section{Ethical Issues Related To Stem Cells}

Human biological materials have been used to cure diseases, but the use of embryos in ESC research has brought about a need to consider religious and moral concerns.

Supporters of ESC research believe in the utilitarian view, which promotes deeds that result in the greater good. ${ }^{12}$ Embryonic stem cell research may destroy embryos, but it also has the potential to treat and cure huge numbers of people. Opponents of ESC research gravitate towards showing compassion for the embryo. One of the arguments against utilitarianism is that it promotes means regardless of morality, even though the result may be moral..$^{13}$ These opponents further argue that ESC therapies are not guaranteed methods for cures and treatments and that the mere possibility of cure is not enough justification to harm embryos.

Those in support of ESC research ask what benefits can be derived in discarding excess embryos from in vitro fertilisation (IVF) rather than using them for research. Hence, they justify "sacrificing" embryos, as they will be used for research that will be beneficial for all in the long term. Some have further argued that they are pro-life. ${ }^{14}$

According to Roger Brownsword, the controversial subject of ESC research can be simplified into human dignity as empowerment and human dignity as a constraint. Those who see human dignity as empowerment believe in the choice of individuals to terminate life, including how embryos are used..$^{15}$ Those who believe in human dignity as a constraint support the idea that humanity itself is dignity and it is compromised when commodified. ${ }^{16}$ This commodification includes not only the use of human organs and tissues but also the destruction of embryos for research; the use of embryos for research is therefore a violation of human dignity because the embryo is seen as a human life. All these views propel two basic questions, for which different perspectives will provide different answers: when does life begin, and what rights do embryos have? ${ }^{17}$ Whatever 
view one takes, embryos can be looked upon with admiration and wonder, a sign of God's magnificent power concerning the miracle of a human life.

The perspective on when life begins is fundamental to embryonic stem cell research. Some believe that an embryo gains human qualities when fertilisation occurs..$^{18}$ Others say an embryo's human nature increases as it develops. ${ }^{19}$ The range of views continues with regard to the inception of life ranging from fourteen days after implantation to four months of pregnancy. Some say embryos do not have human nature until birth. In Islamic belief, the human nature is understood to begin at the time of the 'breathing in' of the human spirit to the embryo, which may occur either from 40 or 120 days after fertilisation.

Those who believe in the human nature of an embryo at fertilisation add that it should have the same rights as living humans. ${ }^{20}$ Those who believe in the gradual development of an embryo's human nature say it should be given some but not all human rights. ${ }^{21}$ Proponents of the belief that embryos are not human until birth say that no human right should apply until birth. ${ }^{22}$

It is also clear that the ethical debate surrounding stem cells draws much of its energy from the abortion debate. ${ }^{23}$ There are people who defend helpless embryos threatened with death by scientists. Frank Young stated: "The devaluation of humans at the very commencement of life encourages a policy of sacrificing the vulnerable that could ultimately put other humans at risk, such as those with disabilities and the aged, through a new eugenics of euthanasia." ${ }^{24}$

Stem cell research is controversial not because of its goals but rather because of the means by which it is conducted. This is why research involving adult stem cells and umbilical cord stem cells is not controversial. The debates regarding ESCs revolve around the destruction of an embryo before it could develop. In addition, cloning is also an issue as it is a way to produce embryos for stem cell research, adding an additional layer of complexity to an already complicated subject.

The controversies surrounding stem cell use start from the nature of the initial extraction: "the removal of the DNA nucleus from the donated oocyte (egg from a female) might be considered the destruction of a potential human life, and the insertion of a DNA nucleus appears to be an asexual creation of a human embryo."25

Scientists thought that by beginning with ESCs, the debate about abortion could be avoided. However, the use of ESCs does not escape the abortion issue completely because Thomson's method relies on using destroyed blastocysts as the source for ESCs, while the Gearhart method relies on aborted fetuses. Those who maintain that abortion is morally wrong and that no right can come from a wrong, argue that if using an aborted fetus's tissue is permitted, one is supporting abortion. This they believe may encourage abortion as a result of its commercialisation. Adding to the ethical issue is the fact that more embryos would be destroyed if scientists obtain the internal cell mass for development into cell lines and for therapy. 
One ethical issue emanates from a religious viewpoint that life begins from conception and that the destruction of an embryo is the same as destroying an adult human being. The manner in which embryos are derived is also significant to the ethical issue, whether left-over cells from fertility clinics, donated eggs and sperms, and cloning. Fertility clinics sometimes buy the sperms and eggs from willing donors. There is also much controversy on the morality of human cloning.

\section{Islamic Ethical Views on Stem Cell Research}

"Abdul Haq Ansari's article titled "Islamic Ethics: Concepts and Prospects" listed numerous Muslim scholars in diverse disciplines who discussed issues of ethics in Islamic thought, including Abu Nasr al Fārābi (d.399/950), Abu cAli Miskawayh (d.421/1030), Nāsir al-Dīn Tusī (d.672/1273) and Jalāl al Dīn Dawānī (d. 908/1502). ${ }^{26}$ Ibn Miskawayh, Fakhr al-Dīn al-Rāzī and al-Ghazālī also made significant contributions in the area of ethics. Ibn Miskawayh developed the threefold division of virtue into wisdom, courage and temperance. Al-Ghazālī in his Revival of the Religious Sciences (Ihy $\bar{a}^{c} u l \bar{u} m$ al-dīn) explained ethics based on character traits $(a k h l a \bar{q})$. Al-Ghazālī supplemented his ethical views with mystical overtones.

The comparable term for ethics in Islam, akhlāq, is seen in Islam as being close to morality. From the Western viewpoint ethics and morality are different because morality to the West is derived from the Latin mores or "morals" while "ethics" derives from the Greek ethos. Morality presupposes what is "felt and done" and ethics what is "appropriate and rational". ${ }^{27}$ In Islamic thought what we mostly find is that ethics is the knowledge of morality or moral value. ${ }^{28}$ Islamic morals, such as good and bad, right and wrong, meritorious and non-meritorious, responsibility and obligation, are defined by the Qur'ān and Sunnah. Furthermore, in the Islamic faith, God and the hereafter play significant roles in shaping the thoughts and thinking of Muslims on morality. The influence of God on the Muslim way of life runs contrary to a modern ethics that leaves little space for God.

Another important point to highlight is the role of Islamic law. Early Muslim scholars discussed whether the human mind is capable of knowing what is good or bad in things or actions, or whether it must depend on revelation in order to distinguish between right and wrong, and whether man should be held accountable for committing wrong out of unintentional ignorance. The discussion of Muslim scholars on such issues shows the important role Islamic law plays in Islamic ethics.

According to Kevin Reinhart, "if most Muslims were asked which science [by science he meant various aspects of Islamic knowledge] is decisive for the determination of right action, they would nominate the Islamic legal sciences." ${ }^{29}$ He further argued that Islamic law is both practical and theoretical and concerns itself with human actions in this world. He added, "The true locus of the 
discussion on Islamic ethics is Islamic law." The reason he adopted such a strong stand is that Islamic law is an example of the moral and legal theory of human behaviour in which initial moral insights are systematically and self-consciously transformed into enforceable guidelines and ideals for all human life.

In Islam, the majority of scholars support the Ash ariyyah and Maturidiyyah view that what is ethical or unethical in Islam must be backed by evidence from the Qur'ān and Sunnah.

Islamic law as a decisive factor in Muslim life is manifest from the way it classifies human actions in terms of categories such as harām (prohibited), wäjib (obligatory), makrūh (disliked), mubāhh (optional) and mandūb (recommended).

\section{Applications from the Sources of Islamic Law}

Does the Qur'ān, which is the first authoritative source of Islamic law, speak about embryonic stem cells? Stem cells are obtained 1-14 days after the fertilisation of embryos. The Qur'ān indeed talks about the development of the human individual in the womb:

We created man from a quintessence (of clay); Then We placed him as (a drop of) sperm in a place of rest, firmly fixed; Then We made the sperm into a clot of congealed blood; then of that clot We made a (fetus) lump; then We made out of that lump bones and clothed the bones with flesh; then We developed out of it another creature. So blessed be Allah, the Best to create! ${ }^{30}$ (al-Mu'minūn 23: 12-14)

The fact that the Qur'ān uses the phrase "then we developed out of it another creature" is an indication that the fetus is perceived as having a human life later in the biological development.

Looking at the sunnah of the Prophet, which is the highest source of Islam after the Qur'an, and what it may say about ESCs, there is no sunnah that directly discusses this subject. There are however hadiths that mention the formation of a baby and when life is breathed into the fetus. One such example from the sunnah relevant to discussions on stem cell research is the hadith which states:

Each of you possesses his own formation within his mother's womb, first as a drop of matter for forty days, then as a blood clot for forty days, then as a piece of flesh for forty days ... Then the soul is breathed into him. ${ }^{31}$

Stem cell studies are a new area of Islamic research. Specific responses to issues would need to be developed through ijtihäd (personal reasoning) and some of the sub-varieties of ijtihād that may offer helpful guidelines on issues of our concern. In this context we may look at the resources of istihsān (juristic preference), mașlahah (public interest) and maqāssid al-sharī ah (objectives of Islamic law). 
In stem cell research, one of the arguments using istihsān is that it serves a greater cause by its potential to cure various kinds of ailments such as heart, kidney and spinal cord diseases. Some scholars using this approach have allowed the use of stem cells for medical purposes. ${ }^{32}$

Two Muslim scholars who allowed stem cell therapy from a mașlahah perspective are Muzammil Siddiqui and Ahmad Kutty. ${ }^{33}$ They based their argument on the interest it would serve when it is fully operational. It is believed that it would serve the public interest by providing remedies to people's ailments.

Imam al-Ghazālī's criteria for mașlahah mursalah that the new act must be necessary, beneficial, highly probable and compatible with the applications of the sharīah can also be applied to stem cell research. This is because (a) transplantation of tissues or cells can save millions of lives and preservation of life is upheld by Islam; (b) it can help many people suffering from various diseases who are in urgent need of transplantation of cells; (c) it has a high probability of effectiveness of working on humans since there is a high record of success on animals; (d) this new science does not contradict any Islamic text.

The discussions on pre-implantation embryos are different from the subject of the Qur'anic verse and hadìth that disapprove of man changing the creation of Allah. This is because firstly, embryonic stem cell studies are not about "changing" but "extracting" from the creation of Allah. Secondly, the fact that to every rule there is an exception, the exception in this case is seen in terms of the extent of benefits that can be derived from avoiding the rule.

Using a maqāssid al-sharī ah approach, Ibn Qayyim al-Jawziyyah noted that such an approach aims to safeguard people's interest and prevent them from harm in this world and the next. To him, if the rulings in Islam do not benefit people, that would be disastrous. ${ }^{34} \mathrm{Al}-\mathrm{Sha} a \bar{i}$ ibi in his popular book titled Al-Muwāfaqāt fí Ușül al-Sharī'ah mentioned public interest as the only principal objective of the Sharĩ $a h .^{35}$

To Imām al-Ghazāli, "the objective of the Sharī'ah is to promote the well being of all mankind, which lies in safeguarding the faith $(d \bar{i} n)$, their human self ( $(a f s)$, their intellect ('aql), their posterity (nasl) and their wealth $(m \bar{a} l)$. Whatever ensures the safeguarding of these five serves the public interest and is desirable. ${ }^{36}$

Among the main objectives of the Shari ${ }^{c} a h$ that relate to our discussion on stem cells are the protection of life (self), progeny and property.

The controversy surrounding stem cells is related to life because of the source of the cells and also the possible harm caused to the source. . The cells can be obtained from fetal tissues following an abortion, from human embryos created by in vitro fertilisation, from adult stem cells and from cloned human embryos; the problem lies in using embryos and fetal materials which some consider as having a life of their own. 
This brings us to whether an embryo or a fetus can or should be given the status of a legal person right from conception or from the time it has attached itself to the wall of the woman's uterus. According to some, Islam says humans comprise both body and soul and since the soul does not exist until after 40 days or 120 days, the embryo comprises only cells and is not yet a human being. The relevant hadīth states:

Narrated 'Abdullah bin Mascud: Allah's Apostle, the true and truly inspired, said, "(In the matter of the Creation of) a human being [he] is put together in the womb of the mother in forty days, and then he becomes a clot of thick blood for a similar period, and then a piece of flesh for a similar period. Then Allah sends an angel who is ordered to write four things. He is ordered to write down his (i.e. the new creature's) deeds, his livelihood, his (date of) death, and whether he will be blessed or wretched (in religion). Then the soul is breathed into him." ${ }^{37}$

Most scholars agreed that the soul is breathed into the human fetus at 120 days after conception and that it is harām to abort a fetus except to save the mother's life. ${ }^{38}$ Abortion after 120 days is permissible only on the basis of avoiding a greater evil such as the death of the mother and the fetus. ${ }^{39}$ Embryonic stem cells are taken from pre-implantation embryos during the first few days after conception. Therefore, our discussion will not dwell further upon the topic of abortion. The Qur'ān does not advise on the specific time ensoulment happens. The Qur'ān states:

But He (God) fashioned him in due proportion and breathed into him something of His spirit. (Al-Sajdah 32:9)

This shows that it was subsequently that God breathed into this embryo of His spirit, which made it human.

Some scholars have also distinguished potential life from actual life. The majority of Sunni and a few Shi'i scholars believe that ensoulment occurs after 40 or 120 days of impregnation when actual life begins. This is based on the hadīth narrated by 'Abdullah bin Mas'ud that was earlier discussed.

To scholars such as Ibn al-Qayyim and Ibn Hajjar al-'Asqalāni, human life begins only when voluntary movements start, but prior to that the embryo has only vegetative life. ${ }^{40}$

There are other scholars who believe that the embryo must be considered a human being and that killing it should be seen as murder. In reality they consider any tools that involve making embryos dispensable must be discarded. Abu Hamid al-Ghazālī, supports this position and argues that even though ensoulment occurs after some time, the embryo is human and should not be destroyed. ${ }^{41}$ Most Shi'i scholars and a very few Sunni scholars support the idea that the embryo 
before ensoulment is a living entity from the moment of conception and judge its eradication as a sin. One of those in support of this is the Muslim president of the Egyptian Medical Syndicate. He totally disagrees with stem cell research using embryos. He said: "Destroying embryos for research is not ethically right, it's not morally right, and it does not conform to our Islamic religion as it stands now". ${ }^{42}$

The protection of future generations and descendants is also one of the aims of Islamic law. Islam recognises that it is in the nature of man to want children. That is why the Qur'ān says that "wealth and progeny are allurements for the life of this world" (al-Kahf 18:46). In another place it mentions the prayers of the believers as saying "O Lord, grant us in our spouses and our offspring the comfort of our eyes" (al-Furqān 25:74).

The discussion on progeny is important to stem cell use because most stem cells are derived from the embryos of people who are seeking a cure for infertility. Islam allows reproductive technologies if the semen and ovum sources come from a legally married husband and wife during the period of marriage.

Scholars in their discussion on stem cells forbid the use of stem cells from illegal sources such as fetal harvesting after conceiving in order to get stem cells and then discarding or aborting the fetus. ${ }^{43}$ They allow the use of stem cells derived from placenta or umbilical cord blood, which can be used with the parents' permission if the fetus is spontaneously aborted or when aborted for therapeutic reasons.

The reference to property as one of the Sharic ah objectives comes from the fact that women's reproductive labour is used to create the surplus embryos that are used in stem cell research. The embryos derive from a human being through technological intervention that involves the manipulation of women's bodies. Obtaining stem cells in such manner takes considerable emotional and psychological investment and a large sacrifice on the part of the woman who gestates the embryos. A woman's volitional and biological labour produces tissues used in stem cell research. We see these as products or the property of her reproductive labour. The embryos and fetal stem cell lines are made from parts of her body. This writer believes that when women begin to see the issues from the perspective of their bodies as property some may see becoming pregnant just to produce more stem cells as a business.

One may also mention the legal maxims, one of which states that "acts are judged by the intention behind them," The Prophet in one of his hadiths said that "Surely, all actions are but driven by intentions and, verily, every man shall have but that which he intended." This hadīth shows that Islam concerns itself with both the external and the internal aspect of a Muslim's life and that any good deed performed by a Muslim must be preceded by sincerity to Allah. Scholars of fiqh also apply this in reaching a judgment in Islam, such as to differentiate a murder from erroneous killing, or theft from misappropriation of money. ${ }^{44}$ 
The issue of intention is also significant in our discussion of stem cells. The intention behind research on stem cells is to cure as many diseases plaguing man as possible. This intention is another reason scholars of Islam have allowed it. For instance, Abdulaziz Sachedina stated that "research on stem cells made possible by biotechnical intervention is regarded as an act of faith in the ultimate will of God as the Giver of life, as long as such intervention is undertaken with the purpose of improving human health." ${ }^{45}$ It is also important to note that there are others who may be motivated solely by commercial purposes; these are the people that the administrators need to guard against. The extraction could easily be turned into a business by encouraging women to get pregnant for the sole purpose of later aborting the fetuses and harvesting the stem cells. It can also be easily commercialised as there are large funds being invested in research, most of which come from the private sector, since there is expectation for an increased demand for stem cells in the future.

The importance of intention is relevant to the use of fetal stem cells which are obtained from aborted fetuses. The intention here is that a fetus should never be aborted nor the mother encouraged to abort with the sole purpose of extracting fetal stem cells. However, in stem cell therapy some physicians feel that since aborted fetuses will ultimately be disposed of, they should be used for something beneficial instead.

Another Islamic legal maxim to note is "Certainty is not overruled by doubt." Although scientists hope to cure many diseases through ESC therapy, there are also many doubts surrounding stem cell research, especially regarding embryonic stem cells. On the issue of certainty, ESCs require close attention. The embryos used often are spare embryos from in vitro fertilisation. Although Islam permits IVF as long as it is performed between a living and legally married couple with their consent, the production of spare embryos and storing them in a freezer for future use is not encouraged..$^{46}$ Another point to be noted related to the issue of certainty is that embryos can be misused, another cause for doubt. The Islamic Fiqh Association in Jeddah met with the Medical Fiqh Association in Kuwait in the year 2000 and they proposed that excess embryos of any form should end their lives naturally without any scientific intervention. ${ }^{47}$ This could be considered a way of killing the embryos, not by utilising the cells, but through neglect. ${ }^{48}$

Islam directs Muslims not to harm or injure anyone; even when injury is caused accidentally, it should be compensated for. The issue of injury comes about as a result of the personhood of an embryo. It is believed that an embryo is a person or potential person. If this is accepted, then it must have basic human rights. Part of the rights it enjoys is that it should not be killed, tortured, nor used for risky medical research. Benefits derived from a fetus do not necessarily outweigh the risks of injury that face an embryo. The embryo's rights must be ensured by those 
in a position to do so as the fetus obviously cannot articulate its own needs, nor does it have the capabilities to take steps that ensure its own well-being. ${ }^{49}$ It is wrong to conduct an experiment when it is certain that the fate of the subject is death, even when such experimentation will benefit the health of others. A human being cannot be sacrificed for the potential good of the whole. ${ }^{50}$

Another legal maxim of relevance here is that "Hardship begets ease and facilitation" just as need or necessity makes the prohibited lawful. Islam is a religion that desires ease for its followers. The Prophet, peace be upon him, was reported to have said, "There is a cure for every ailment, though we may not know it yet." ${ }^{11}$ This shows that Islam encourages people to research and look for cures for illnesses.

The principle of hardship in Islam holds that the prevention of harm has priority over possible benefit. Some believe that one causes harm by killing the embryo and since medical practitioners are still trying to determine how much benefit would be derived from the use of ESCs, it is very difficult for some to support it.

Those, however, who want to examine it from a positive angle rely on the principle which stipulates that necessity renders the prohibited permissible. Therefore, since embryonic stem cell research aims at curing people from life threatening ailments, the research should be allowed to continue.

\section{Conclusions and Recommendations}

The writer underscored the relationship between Islamic law and Islamic ethics and then elaborated upon the standards set by Islamic ethics that are to be used in judging how embryonic stem cells should be utilised. This examination aimed to show the respect Islam places on different stages of human life, from the zygote stage to development into a full human being. It is with this understanding that the progressive support Islam gives to stem cell research can be understood.

A benefit from this study can be explained in a metaphor proposed by an English author about little boys playing football on an island; at the very edges of the field there are cliffs, which fall hundreds of feet, with waves crashing below against the rocky shore. The boys are playing, but only within the middle twenty yards - no one wants to risk a corner kick. Then, someone helped by building a strong fence right at the edges of the field; with this fence, they could now play the full field. Similarly, if we can clearly define the Islamic moral or ethical boundaries, we can help medical science in its field of enquiry in a positive way by ensuring that it operates within the limits of the sacred law.

From an Islamic ethics standpoint on stem cell research (especially embryonic stem cells), it can be argued that there is a point of contact between Islamic ethics and medical science. This is especially so when considering the developmental 
stages of human life. This association provides avenues for science and religion to work in harmony towards enhancing the life of mankind. The lives of people in terms of health and its related issues in most countries have improved through various scientific and technological discoveries, which, for instance, have led to the development of controlled pregnancy, artificial insemination by husbands, and organ transplantation, among others. All these are well appreciated in Islam. What stands clear however, is that life is sacred and if it must be destroyed, it must be for a genuine and just cause. Unlike the Vatican approach, which rejects absolutely the destruction of the embryo, through the understanding of Islamic ethical flexibility, the issue can be seen in a better and more hopeful light.

Therefore, deriving from this investigation, the following policy recommendations are offered:

- Islamic ethical guidelines are required to be formulated to assist Muslim scientists in applying Islamic ethical principles to various medical problems, especially as they affect the dignity and totality of the human person.

- The Islamic ethical principles that call for moderation and striking a middle course (wasatiyyah) should be closely applied to all stem cell applications. In the debate on stem cell research, commonly people take extreme positions, either the position that the embryo is a person or that it is property. There is the extreme position of the person who sees the embryos as a human being from the moment of conception and forbids research on the embryo outside or inside the body. The other extreme position sees the embryo as mere property and reduces it to a clump of cells. Using the word "murder" for the destruction of ESCs is not acceptable. The way forward is to avoid looking at the issue in a simplistic fashion of person versus property. Although it is not yet a person, it is without doubt the developing form of human life in its early stages and therefore warrants a high degree of respect. Within this argument, it is our expectation that in the world of contemporary medical science, a well formulated biomedical ethical theory that is well grounded in Islamic ethical principles will be formulated in order for stem cell research to move forward. It will guide physicians and researchers alike in striking a balance as well as a morally acceptable foundation in difficult medical cases, especially those having to do with the early developmental stage of human life. Stem cell therapy as a new medical treatment should be allowed because it has many benefits for people suffering from various ailments. The benefit in it is greater than the harm. 


\section{Notes}

* Fahm AbdulGafar Olawale, a native of Nigeria with an M.A. from International Islamic University Malaysia, currently pursues his $\mathrm{PhD}$ at IIUM.

1. Louis P. Pojman (ed.), Ethical Theory: Classic and Contemporary Readings (Canada: Wadsworth, 2002), 1.

2. Peter Singer (ed.), Ethics (Oxford: Oxford UP, 1994), 4.

3. See Ann K.S. Lambton, State and Government in Medieval Islam: An Introduction to the Study of Islamic Political Theory: The Jurists (Oxford: Oxford UP, 1981).

4. Attaullah Siddiqui, "Ethics in Islam: Key Concepts and Contemporary Challenges," Journal of Moral Education 26, no. 4 (1997), 423.

5. See Muhammad Umar al-Dīn, The Ethical Philosophy of al-Ghazālī (Lahore: SH Muhammad Ashraf, 1991), 53.

6. Ahmad ibn-Muhammad Miskawayh, The Refinement of Character, transl. Constantine K. Zuraykh (Beirut: American University of Beirut, 1968), 1.

7. Al-Ghazālī, Ihyā ulūm dīn, vol. 3, transl. Fazlul Karim, (New Delhi: Islamic Book Services, 1998), 54.

8. See Zaki Mubarak, Al-akhlāq inda al-Ghazālī (Ethics of al-Ghazālī) (Cairo: Dārul al-Kitab alArabi, 1924), 113-114.

9. Attaullah Siddiqui, "Ethics in Islam," 424.

10. Nancy Gibbs, "Stem Cells: The Hope and The Hype," Time Magazine, 30 July 2006.

11. Cells are the building blocks of life. In humans there are at least 200 different types. They all have their own functions. All cells have a surrounding semi-permeable membrane that acts as a selective barrier, controlling the flow of materials into and out of the cell. A cell also has a nucleus, which can be found in its centre. Ribosomes, another important structure and located in the cytoplasm of the cells rather than inside the nucleus, are the site of protein synthesis. Deoxyribonucleic acid (DNA) serves as the molecule of heredity. It can be found in the cell nucleus. DNAs are the key to understanding how information is stored and carried from one generation to another. In discussing DNA we must also talk about genes. These are the shorter sequences of DNA found on chromosomes and are the actual units of hereditary. The gene codes influence characteristics of the cell and invariably the organism. The sequence of DNA in each organism's cells is essentially identical. The difference between cells largely depends on which genes are expressed or turned on at a given time. As all the cells contain the same DNA sequence, possibilities exist that cells can be converted from one type to another, therefore forming the basis of some potential hESC-based therapies.

12. David Hollinger, "Stem Cell and Our Moral Culture," The Center for Bioethics and Human Dignity, 15 November 2000, cited by Afsheen Sayed, "Current United States Policy Considerations and a Recommendation for an Alternative Policy based on Guidelines from Existing International Policy," M.Sc. thesis, University of Texas School of Public Health, 2007, 4.

13. Ibid., 5 .

14. See Jason Braswell, "Federal Funding of Human Embryo Stem Cell Research: Advocating a Broader Approach," Chicago-Kent Law Review 78, no. 1 (2003), 423 \& 429, cited by Afsheen Sayed, "Current United States Policy."

15. Ibid.

16. Ibid.

17. Ibid.

18. Allison C. Ayer, "Stem Cell Research: The Laws of Nations and a Proposal for International Guidelines," Connecticut Journal of International Law 17, no. 2 (2002), 393 \& 399, cited by Afsheen Sayed, "Current United States Policy".

19. Ibid.

20. Ibid.

21. Ibid.

22. Ibid., 8 .

23. Ibid., 25.

24. Frank E. Young, "A Time for Restraint,” Science 287, no. 5457 (25 February 2000), 2424. 
25. Ted Peters, Playing God?:Genetic Determinism and Human Freedom (New York and London: Routledge, 2003), 180.

26. See Abdul Haq Ansari, "Islamic Ethics: Concept and Prospect," American Journal of Islamic Social Science 6, no. 1 (1989), 81.

27. Attaullah Siddiqui, "Ethics in Islam," 423.

28. Ibid.

29. Kevin Reinhart, "Islamic Law as Islamic Ethics," The Journal of Religious Ethics 11, no. 2 (1983), 186.

30. Abdullah Yūsuf 'Ali, The Holy Qur'an: Text Translation and Commentary (Maryland: Amana Corporation, 1989), 845-846.

31. Al-Bukhari, Collections of Hadith (Cairo: Dar Al-Fikr), vol. 4, book 54, no. 430.

32. Muhammad Na'īm Yāsīn, Abhāith fiqhīyyah fi qadaya țibbìyyah mu'așsarah (Amman: Dār alNafă'is, 1996), 120.

33. Islam Online, http://www.islamonline.net/servlet/Satellite?pagename=IslamOnline-English-Ask Scholar/FatwaE /FatwaE\&cid=1119503545118 (accessed on 15 July 2010).

34. Muhamad Akram, 14.

35. Ibid.

36. M. Umer Chapra, The Future of Economics: An Islamic Perspective (Leicester: The Islamic Foundation, 2000), 118.

37. Al-Bukhari, Collections of Hadith (Cairo: Dar Al-Fikr), vol. 4, book 54, no. 430.

38. Muhammad Ahmed Al-Mabid, Maslahah hifz al-nafs fi al-shari 'a al-Islamiyyah (Cairo: Mu'ssasah al-Mukhtar, 2005), 203.

39. 'Umar Ibn Muhammad ibn Ibrahim Ghanim, Ahkam al-janin fi al-fiqh al-Islami (Jeddah: Dar alAndalus al-Khadra', 2001), 115-116.

40. Muhammad Ali Albar, The Creation of Man between Medicine and the Qur'an (Jedda: Arabia Publishing House, 2002, $5^{\text {th }}$ ed.)

41. Fatima Agha Al-Hayani, "Biomedical Ethics: Muslim Perspectives on Stem Cell Research and Cloning," Zygon 43, no. 4 (2008), 791.

42. Christi Dabu, "Stem-cell Science Stirs Debate in the Muslim World, Too," The Christian Science Monitor, 22 June 2005.

43. See Muslim World League, Islamic Fiqh (Jurisprudence) Council Conference, 13-17 December 2003, Makkah, Saudi Arabia, Fatwa (Juristic opinion), cited in Shahid Athar, "Enhancement Technologies and the Person: An Islamic View," The Journal of Law, Medicine and Ethics 36, no. 1 (2008), 62.

44. Mohammad Hashim Kamali, "Qawa'id al-Fiqh: The Legal Maxims of Islamic Law," The Association of Muslim Lawyers, available online at http://www.sunnah.org/fiqh/usul/Kamali Qawaid_al-Fiqh.pdf (accessed on 29 July 2010), 3.

45. Abdulaziz Sachedina, "Islamic Perspectives on Research with Human Embryonic Stem Cells," in: National Bioethics Advisory Commission (ed.), Ethical Issues in Human Stem-Cell Research, vol. 3: Religious Perspectives (Rockville MD: Government Printing Office, 2000), 5.

46. S. Aksoy, "Making Regulations and Drawing Up Legislation in Islamic Countries under Conditions of Uncertainty, with Special Reference to Embryonic Stem Cell Research," Journal of Medical Ethics 31, no. 7 (2005), available online at http://jme.bmj.com/content/31/7/399.full?rss=1 (accessed on 15 September 2010).

47. Ibid.

48. Ibid.

49. Marin Gillis, "The Human Stem Cell Debate and the Commodification of Women: Ethical Considerations," Ph.D. dissertation, University of Calgary, 2005, 87.

50. Ibid.

51. S. Aksoy, "Making Regulations"; Al-Bukhari, Al-Sahih, Kitab al-Tib, vol. 7 (Istanbul: Al-Maktaba al-Islami, 1979), 11. 